\title{
Testing the diagnosis and recommendation integrated system (DRIS) on high country white clover-based pastures
}

\author{
M.B. JONES', A.G. SINCLAIR*, M.J.S. FLOATE ${ }^{2}$ and C.C. BOSWELL ${ }^{2}$ \\ 'University of California, Davis \\ ${ }^{2}$ Ministry of Agriculture and Fisheries,
}

Invermay Agricultural Centre, Private Bag, Mosgiel

\begin{abstract}
Plant tissue analysis is useful to assay plant nutrient status, but has limitations due to changes in nutrient concentrations with physiological age, and variation between plant parts. The Diagnosis and Recommendation Integrated System (DRIS) uses nutrient ratios calculated from plant tissue analyses to evaluate plant nutrient status. It calculates indices for each nutrient, and ranks them in order of their deficiency. An exploratory assessment of DRIS has been conducted for New Zealand high country pasture using chemical analysis and yield data from field trials. In this limited assessment, DRIS consistently ranked $\mathrm{S}$ and $\mathrm{P}$ deficiencies in the same order as indicated by yield responses to fertiliser treatments. It was generally successful in distinguishing between deficient and nondeficient conditions. Results are considered-to justify a more comprehensive evaluation of DRIS for New Zealand pastures.
\end{abstract}

K eywords DRIS, plant analysis, $\mathrm{P}$ deficiency, $\mathrm{S}$ deficiency

\section{Introduction}

Traditionally, the concentration of essential nutrients in plants compared to a critical value (i.e. the minimum concentration associated with the desired productivity) has been used to monitor the nutritional status of a crop. Another method, called the Diagnosis and Recommendation Integrated System (DRIS), has been proposed to assay the nutrient status of a number of crops (Beaufils 1957; Cornforth \& Steele 1981; Walworth \& Sumner 1987). DRIS uses ratios of nutrients to diagnose nutrient deficiencies in a crop; this appears to have some advantages because nutrient ratios in most plants are less affected by time of sampling and plant part sampled than are nutrient concentrations. The nutrient ratios of plants being assayed are compared with ratios in high yielding plants. These ratios are called "norms".

Little work has been reported using DRIS to assay clover pastures (Jones et al. 1986), but there have been many New Zealand studies on white clover (Trifolium repens) responses to phosphorus and sulphur. In this paper we describe the derivation of DRIS norms for white clover in oversown tussock grasslands in the South Island, New Zealand, and the calculation and assessment of DRIS indices in clover samples in a $\mathrm{P}$ and $\mathrm{S}$ fertiliser trial.

\section{Source of data and derivation of DRIS norms}

Mixed herbage dry matter (DM) production and chemical analysis of 996 white clover samples were obtained from high country trial data. The data were from individual plots in nine $\mathrm{P}$ and $\mathrm{S}$ fertiliser and lime trials. These trials were located on yellow-brown earths_on -the-Remarkables (Eloate-et-al.-1.985) and-at Crookston in West Otago, and on yellow-grey earths in the Mackenzie Country (McIntosh et al. 1985). DM cuts were taken between 1981 and 1988, and usually occurred between November and April. The DM yields were converted to yields relative to the highest yield at each site and date. Samples having a relative yield of $90 \%$ or higher (about $10 \%$ of the samples) were selected as a high yielding population. Norms and standard deviations are given in Table 1 . The norms are the average of the clover nutrient concentration ratios from high yielding plots.

\section{Calculation and assessment of DRIS indices}

The DRIS indices were computed using a modification reported by Jones (1981). The calculation of the $\mathrm{N}$ index is presented as an example of how the index for each element was computed.

$\mathrm{N}$ index $=[-\mathrm{f}(\mathrm{S} / \mathrm{N})-\mathrm{f}(\mathrm{P} / \mathrm{N})-\mathrm{f}(\mathrm{Ca} / \mathrm{N})-\mathrm{f}(\mathrm{K} / \mathrm{N})] / 4$, where $f(S / N)=(\% \mathrm{~S} / \% \mathrm{~N}$ in sample $-\% \mathrm{~S} / \% \mathrm{~N}$ norm) $\times 10 \%$ sd, sd is the standard deviation of this norm's population and the number 10 is an arbitrary multiplier to make the index a whole number. 
Table 1 DRIS reference norms for high yielding white Clover from oversown pastures in the South Island high country.

\begin{tabular}{lll}
\hline Component & $\begin{array}{l}\text { Norm } \\
\text { value }\end{array}$ & $\begin{array}{l}\text { Standard } \\
\text { deviation }\end{array}$ \\
\hline Relative yield & 95.6 & 3.56 \\
\% N & 3.69 & 0.573 \\
\% $\mathrm{S}$ & 0.21 & 0.044 \\
$\mathbf{\%} \mathrm{P}$ & 0.31 & 0.068 \\
\% $\mathrm{Ca}$ & 1.54 & 0.279 \\
$\mathbf{\%} \mathrm{K}$ & 2.41 & 0.799 \\
$\mathrm{~S} / \mathrm{N}$ & 0.057 & 0.0082 \\
$\mathrm{P} / \mathrm{N}$ & 0.083 & 0.0148 \\
$\mathrm{Ca} / \mathrm{N}$ & 0.428 & 0.1073 \\
$\mathrm{~K} / \mathrm{N}$ & 0.656 & 0.211 \\
$\mathrm{P} / \mathrm{S}$ & 1.483 & 0.278 \\
$\mathbf{C a} / \mathbf{S}$ & 7.66 & 1.96 \\
$\mathrm{~K} / \mathrm{S}$ & 11.76 & 3.96 \\
$\mathbf{C a} / \mathbf{P}$ & 5.30 & 1.55 \\
$\mathrm{~K} / \mathrm{P}$ & 8.12 & 2.73 \\
$\mathrm{Ca} / \mathbf{K}$ & 0.738 & 0.388 \\
\hline
\end{tabular}

Indices were calculated for clover herbage from a spring cut of a $\mathrm{P}$ and $\mathbf{S}$ fertiliser trial on a yellow-grey earth soil at Glencairn in the Mackenzie Basin. The trial had been established by oversowing the tussock grassland and was in its fifth year. Fertiliser treatments applied at establishment at the rates shown in Table 2 had been reapplied about 15 months prior to the cut used for this assessment of DRIS. On the basis of DM yields and fertiliser applications we have assessed the relative deficiencies of $\mathbf{S}$ and $\mathrm{P}$ in each treatment combination (Table 2). The site was strongly responsive to $\mathbf{S}$ and moderately responsive to $\mathrm{P}$. Thus in the treatment that received neither $\mathbf{S}$ nor $\mathrm{P}, \mathbf{S}$ was much more deficient than $\mathrm{P}$ $(\mathrm{S}>>\mathrm{P})$, as shown by the large $\mathrm{DM}$ responses to $\mathrm{S}$. However, overall DM response to $\mathrm{P}$ was also evident; therefore $\mathrm{P}$ was, also deemed deficient in this treatment $(\mathrm{P}>\mathrm{Nil})$.
DRIS indices (Table 2) corresponded closely with the assessed order of deficiences. The nutrient assessed to be the more deficient in any treatment always had the more negative DRIS index. Moreover, DRIS appeared to be successful in separating deficient from non-deficient conditions. Ten of the eleven conditions assessed to be deficient had DRIS indices more negative than -8 , with the one exception having DRIS index of $\boldsymbol{- 5}$. Ten of the eleven conditions assessed as non-deficient had DRIS indices less negative than -8 , with the one exception having DRIS index of -9 . This closely matches common interpretations of DRIS, in which values within the range -5 to -10 are generally used to differentiate between deficient and non-deficient conditions (Russell \& Sheaffer 1986).

The relative deficiencies of $\mathbf{S}$ and $\mathrm{P}$ are much less apparent from the $\% \mathbf{S}$ and $\mathbf{\%} \mathrm{P}$ data (Table 2), although these data provide the basis for the DRIS indices. DRIS appears to be a successful method of expressing the plant chemical data in terms of relative nutrient deficiencies.

\section{Conclusions}

This exploratory assessment of DRIS on tussock grassland clover-based pastures has provided support for a more comprehensive evaluation of the system. DRIS appears to hold considerable promise as a method of using plant chemical analysis data to diagnose relative deficiency of different nutrients.

\section{ACKNOWLEDGEMENTS}

The authors wish to thank the following people who helped gather data for this paper: Barbara Chalmers, Dennis Enright, Roger Littlejohn, Chris Smith and Brian Swanney. We thank Mike Center who wrote the DRIS program and Murray Penno who modified it, The senior author also thanks the University of California for granting sabbatical leave and MAF for a Senior Research Fellowship which made this study possible.

Table 2 Relation of DRIS indices to $\mathrm{S}$ and $\mathrm{P}$ deficiencies in a spring cut $(29 / 11 / 83)$ of a high-country fertiliser trial

\begin{tabular}{|c|c|c|c|c|c|c|c|}
\hline \multicolumn{2}{|c|}{$\begin{array}{l}\text { Nutrients applied } \\
\text { (kg/ha) }\end{array}$} & \multirow[t]{2}{*}{$\begin{array}{l}\text { Total DM yield } \\
\text { (kg/ha) }\end{array}$} & \multicolumn{2}{|c|}{$\begin{array}{l}\text { Nutrients in } \\
\text { clover }\end{array}$} & \multirow[t]{2}{*}{$\begin{array}{l}\text { Assessed relative } \\
\text { deficiences }\end{array}$} & \multirow{2}{*}{$\begin{array}{c}\text { DRIS } \\
\mathbf{S}\end{array}$} & \multirow{2}{*}{$\begin{array}{c}\text { indices } \\
\text { P }\end{array}$} \\
\hline$S$ & $\mathrm{P}$ & & $\% \mathrm{~s}$ & $\% \mathrm{P}$ & & & \\
\hline 0 & 0 & 722 & 0.11 & 0.19 & $\mathrm{~S}>>\mathrm{P}>\mathrm{Nil}$ & -28 & -10 \\
\hline $25^{\prime}$ & 0 & 1755 & 0.12 & 0.21 & $\mathrm{~S}>\mathrm{P}>\mathrm{Nil}$ & -22 & -5 \\
\hline 50 & 0 & 1192 & 0.13 & 0.17 & $\mathrm{~S} \approx \mathrm{P}>\mathrm{Nil}$ & -16 & -23 \\
\hline $100^{\prime}$ & 0 & 2395 & 0.16 & 0.19 & $\mathrm{P}>\mathrm{S}=\mathrm{Nil}$ & -7 & -23 \\
\hline 0 & $40^{\prime}$ & 1058 & 0.10 & 0.21 & $\mathrm{~S}>>\mathrm{P}=\mathrm{Nil}$ & -37 & -1 \\
\hline $25^{\prime}$ & $40^{\prime}$ & 1620 & 0.11 & 0.25 & $\mathrm{~S}>\mathrm{P}=\mathrm{Nil}$ & -36 & +7 \\
\hline 50 ' & 40, & 2485 & 0.15 & 0.28 & $\mathrm{~S}>\mathrm{P}=\mathrm{Nil}$ & -9 & +3 \\
\hline $100^{\prime}$ & $40^{\prime}$ & 3283 & 0.16 & 0.24 & $S=P=$ Nil & -9 & $\begin{array}{l}-6 \\
-6\end{array}$ \\
\hline $100^{\prime}$ & $40^{\prime}$ & 3241 & 0.20 & 0.32 & $\mathrm{~S}=\mathrm{P}=\mathrm{Nil}$ & -3 & +4 \\
\hline $100^{3}$ & 0 & 2533 & 0.19 & 0.19 & $\mathrm{P}>\mathrm{S}=\mathrm{Nil}$ & -3 & -24 \\
\hline \multirow[t]{2}{*}{$100^{3}$} & $40^{3}$ & 3344 & 0.20 & 0.32 & $\mathrm{~S}=\mathrm{P}=\mathrm{Nil}$ & -5 & +2 \\
\hline & & SED 555 & & & & & \\
\hline
\end{tabular}

Applied 51 and 15 months previous to sampling

2 Applied annually for 5 years

3 Applied annually for 4 years 


\section{REFERENCES}

Beaufils, E.R. 1957. Research for rotational exploitation of Hever brasiliesis using a physiological diagnosis based on the mineral analysis of various parts of the plant. Fertilite 3: 27-38.

Cornforth, I.S.; Steele, K.W. 1981. Interpretation of maize leaf analysis in New Zealand. NZ journal of experimental agriculture 9: 91-96.

Floate, M.J.S.; McIntosh, P.D.; Risk, W.H.; Enright, P.D.; Smith, L.C. 1985. Effects of fertilisers and environments on lotus production on high country acid soils in Otago. Proceedings of the NZ Grassland Association 46: 111 . 118

Jones, M.B.; Centre, D.M.; Vaughn, C.E.; Bell, F.L. 1986. Using DRIS to assay nutrients in subclover. Californian agriculture 40: (9\& 10): 19-21.

McIntosh, P.D.; Sinclair, A.G.; Enright, P.D. 1985. Responses of legumes to phosphorus and sulphur fertilisers on 2 toposequences of North Otago soils, New Zealand. NZ journal of agricultural research 28: 505-515.

Russelle, M.P.; Sheaffer, C.C. 1986. Use of the diagnosis and recommendation integrated system with alfalfa. Agronomy Journal 78: $557-560$

Walworth, J.L.; and Sumner, M.E. 1987. The Diagnosis and Recommendation Integrated System (DRIS). Advances in soil science 6: 149-188. 